\title{
Factors associated with lowered intelligence in homozygous sickle cell disease
}

\author{
Susan Knight, Atul Singhal, Peter Thomas, Graham Serjeant
}

\begin{abstract}
The intelligence quotient (IQ) of 60 patients with homozygous sickle cell (SS) disease and 60 age and sex matched controls with a normal haemoglobin (AA) genotype aged 15-18 years, followed up in a cohort study from birth, was assessed by the Wechsler intelligence scales for children or for adults. IQ appeared to be normally distributed in both genotypes but mean values in SS disease were 5.6 points $(95 \%$ confidence interval (CI) 1.0 to $10 \cdot 2)$ lower than in AA controls $(p=0 \cdot 016)$. The difference occurred in both verbal (5.5 points, $p=0.017)$ and performance (5.0 points, $p=0.044)$ subscales of the IQ score and the IQ defect in SS disease was associated with a significantly lower attention factor score $(p=0.005)$ but not with other factor scores. The genotype difference in IQ was not accounted for by differences in parental occupational level, school absenteeism, or school drop out, or reported activity level. In SS disease, IQ was not related to mean steady state haemoglobin, fetal haemoglobin, or mean cell haemoglobin concentration, or clinical severity as judged by the frequency of painful crises, hospital admission, or sick visits. IQ, at age 15-18 years, correlated with the patients' height at all ages from 1 to 10 years (partial correlations increasing from $0.14(p=0.15)$ at age 1 to 0.27 $(p=0.004)$ at age 10). Adjusting for height reduced the mean genotype difference in IQ to $5 \cdot 5(95 \%$ CI 0.6 to $10 \cdot 3)$ points at age 1 and to $2 \cdot 6$ points $(95 \% \mathrm{CI}$ to $-2 \cdot 3,7 \cdot 5)$ at age 10. Prepubertal height therefore accounted for much of the genotype difference in IQ. It is speculated that early factors, possibly nutritional, contribute to both impaired growth and mental development in sickle cell disease. (Arch Dis Child 1995; 73: 316-320)
\end{abstract}

Keywords: intelligence, homozygous sickle cell disease, poor growth.

Department of Child Health and the Medical Research Council Laboratories (Jamaica), University of the West Indies, Mona, Kingston 7, Jamaica

S Knight

A Singhal

P Thomas

G Serjeant

Correspondence and reprint requests to:

Professor Serjeant.

Accepted 18 May 1995

Intellectual impairment and subtle neuropsychiatric deficits have been reported in homozygous sickle cell (SS) disease ${ }^{1-4}$ and are usually assumed to reflect school absenteeism or other factors associated with chronic ill health. Other possibilities include impaired neurodevelopment or subclinical brain damage as evidenced by the recent more sensitive imaging procedures such as magnetic resonance. ${ }^{56}$ In the Jamaican cohort study, a representative sample of patients with SS disease and age and sex matched controls with a normal haemoglobin (AA) genotype have been followed up from birth with regular assessments of clinical features, haematology, and social indices. We have compared the intelligence quotient (IQ) measured by psychometric testing in patients and controls when aged 15-18 years, and assessed the relative contributions of clinical, haematological, and social factors to the genotype difference.

\section{Patients and methods}

Subjects attended the sickle cell clinic of the University Hospital of the West Indies and participated in a cohort study identified by the neonatal screening of 100000 consecutive normal deliveries at the main government maternity (Victoria Jubilee) hospital. ${ }^{7}$ The first 125 babies with an SS phenotype, born between June 1973 and January 1976, were each matched with two normal (AA) controls of the same sex, born closest in time to the index case giving a total group of $250 \mathrm{AA}$ controls. Of the 125 subjects with an SS phenotype, 18 were found to have other genotypes such as sickle cell $\beta^{0}$ thalassaemia or sickle cell hereditary persistence of fetal haemoglobin, leaving 107 subjects with an SS genotype. By the study date (January 1991-January 1992), 29 had died and seven emigrated leaving a group of 71 SS patients who were aged 15-18 years. Of these, 11 patients were not available (seven lived distant from Kingston, two defaulted, and two were consistently unwell at clinic visits during the study period) and IQ was assessed in the remaining $60 \mathrm{SS}$ patients ( 30 male, 30 female). Of the two AA controls originally selected for each of these 60 patients, a single control remained available for 26 cohorts, neither control in five, and both controls in 29 . For the latter group, the first of the two controls attending the clinic for routine assessment was interviewed, and for the five without controls, the unused sex matched control of an adjacent patient with birth date within three months of the index case was taken. All subjects were interviewed at the sickle cell unit and were clinically well at the time of assessment.
INTELLIGENCE TESTS revised (WISC-R), ${ }^{8}$ designed for subjects under 17 years, was given to 38 such subjects and inadvertently to nine subjects over this age. The Wechsler adult intelligence scale revised (WAIS-R), ${ }^{9}$ designed for subjects 16 years and above, was given to 73 subjects.
The Wechsler intelligence scale for children - 
Subjects aged 16-17 years were given either test depending on availability (17 received WISC-R and 25 WAIS-R). Performance on the two tests has been reported to be highly correlated $(r=0 \cdot 88)^{9}$ but as this does not imply close agreement, the possible influence of test type on genotype differences was assessed in the analysis. The wording of test items and directions were modified for local conditions and the vocabulary and picture arrangement subtests omitted in accordance with previous studies of the WISC-R in Jamaica. ${ }^{10}$ Subtest scores were prorated as directed in the respective manuals, and factorised according to the method of Bannatyne. ${ }^{11}$

\section{SOCIAL FACTORS}

The number of social, physical, and intellectual activities engaged in and the degree of participation, was assessed by the activity subscale of the social competence scale in the child behavior checklist (self report form) and depicted as $T$ scores according to the manual. ${ }^{12}$ Days absent from school during the period September-May before the study were obtained from classroom registers for 17 pairs where both patient and control were still at school.

Socioeconomic status was determined from (i) the occupation of main guardian (termed 'parental') ranked in three categories (skilled, semiskilled, unskilled) on a scale developed for Jamaica ${ }^{13}$; (ii) indices of overcrowding (persons per room); (iii) sanitation (toilet type and location); and (iv) availability of electricity and water. Socioeconomic status ${ }^{14}$ was scored by structured interview in all subjects (except one AA control who emigrated during the study).

\section{CLINICAL SEVERTTY}

Clinical severity of SS disease was assessed by the number of hospital admissions, sick clinic visits, and painful crises from birth to the date of IQ assessment. It is recognised that the first two events may be influenced by arbitrary factors but the combination of indices was considered a better indication of overall clinical severity than any single index. Morbidity data were believed to be complete as the sickle cell clinic was the primary, and generally the only, source of health care, and events occurring between clinic visits were recalled at each attendance.

\section{HAEMATOLOGY}

Haematological indices were measured in a Coulter $S$ plus IV (Coulter Electronics, Hialeah, Florida) and the mean cell haemoglobin concentration (MCHC) calculated from the spun microhaematocrit. Fetal haemoglobin was measured by alkali denaturation. ${ }^{15}$ The number of $\alpha$ globin genes was determined by standard DNA technology using restriction endonuclease analysis of DNA obtained from peripheral blood. Average steady state values after the age of 5 years were used for assessing the influence of haematological indices on IQ.
Serum iron and iron binding capacity were measured by the method of Beale et al annually but the analysis was confined to values at the second (serum iron $36 \mathrm{AA}, 47 \mathrm{SS}$; transferrin saturation $32 \mathrm{AA}, 46 \mathrm{SS}$ ) and eighth birthdays (serum iron $40 \mathrm{AA}, 49 \mathrm{SS}$; saturation $38 \mathrm{AA}$, $48 \mathrm{SS}) .{ }^{16}$

\section{GROWTH AND DEVELOPMENT}

Birth weight and head circumference were measured as described ${ }^{17}$ and height and weight at three month intervals coinciding with birthday visits using standard protocols. ${ }^{18}$ To avoid potential bias from exclusion of cases without appropriate height data near to their birthday, standard deviation (z) scores were calculated for both genotypes from the nearest height to each age from 1 to 10 years using height standards previously derived from SS patients in the cohort study. Skinfold thickness at biceps, triceps, subscapular, and suprailiac sites were measured using skinfold calipers (Holtain Instruments Ltd, Crymmych) and standard protocols and data are presented as the sum of all four skinfolds at age 8 years ( \pm 3 months).

The relationship of adolescent growth to IQ in both genotypes was assessed using a mathematical model (Preece-Baines model 1), ${ }^{19}$ which describes the timing of the adolescent growth spurt in each individual. Height data, at six month intervals ( \pm 2 months) from the age of 1 year, were fitted to this model by computer using the method of least squares. The ages at growth spurt 'take off' and peak height velocity, derived from this model were available for all except one AA subject and were used for analysis.

\section{ANALYSIS}

Distributions that were markedly skewed (fetal haemoglobin, serum iron, transferrin saturation, weight, and sum of skinfolds) were normalised using a $\log _{e}$ transformation before analysis. Since SS and AA matched pairs were not always given the same IQ test; unmatched methods of analysis were used. The mean genotype difference in IQ scores with the WAIS-R test was not statistically different from that with the WISC-R test $(p=0 \cdot 13)$, and were therefore assumed to be the same for each test type. With the WAIS-R test, average values were 11.9 points $(95 \%$ confidence interval (CI) $7 \cdot 2$ to $16 \cdot 6$ ) higher than with the WISC-R test, so test type was controlled for in all analyses. The mean IQ in the two genotypes, taking test type into account, were compared using analysis of variance, and adjusting for covariates by multiple regression. The regression line of IQ on each covariate was

Table 1 IQ measured by WISC-R and WAIS-R tests by genotype

\begin{tabular}{llllll}
\hline & \multicolumn{1}{l}{$A A$} & & \multicolumn{2}{l}{$S S$} \\
\cline { 2 - 3 } \cline { 5 - 6 } Test type & No & Mean (SD) & & No & Mean (SD) \\
\hline WISC-R & 19 & $73 \cdot 5(12 \cdot 7)$ & & 28 & $72 \cdot 3(13 \cdot 7)$ \\
WAIS-R & 41 & $89 \cdot 2(13 \cdot 5)$ & & 32 & $80 \cdot 8(9 \cdot 2)$ \\
\hline
\end{tabular}


Table 2 Mean genotype (SS, AA) differences on full scale, subscale, and factorised IQ scores

\begin{tabular}{|c|c|c|}
\hline & $\begin{array}{l}\text { Mean genotype } \\
\text { difference } A A \text { relative } \\
\text { to } S S^{\star}(95 \% C I)\end{array}$ & $\begin{array}{l}\text { Significance } \\
\text { ( } p \text { value) }\end{array}$ \\
\hline $\begin{array}{l}\text { Full scale } \\
\text { Subscale }\end{array}$ & $5.6(1.0$ to 10.2$)$ & 0.016 \\
\hline $\begin{array}{l}\text { Verbal } \\
\text { Performance }\end{array}$ & $\begin{array}{l}5.5(1.0 \text { to } 10.0) \\
5.0(0.1 \text { to } 9.9)\end{array}$ & $\begin{array}{l}0.017 \\
0.044\end{array}$ \\
\hline $\begin{array}{l}\text { Factorised } \\
\text { Reasoning/ }\end{array}$ & & \\
\hline $\begin{array}{l}\text { comprehension } \\
\text { Visual-spatial ability } \\
\text { Sequencing/attention } \\
\text { Acquired knowledge }\end{array}$ & $\begin{array}{l}4.4(-0.4 \text { to } 9 \cdot 3) \\
3 \cdot 6(-1.6 \text { to } 8 \cdot 8) \\
6 \cdot 7(2.0 \text { to } 11 \cdot 3) \\
2 \cdot 1(-3.9 \text { to } 8 \cdot 2)\end{array}$ & $\begin{array}{l}0.07 \\
0.17 \\
0.005 \\
0.49\end{array}$ \\
\hline
\end{tabular}

^Adjusted for test type.

assumed to be parallel in both genotypes (homogeneity of regression) unless there was evidence to the contrary. The matching variables, age and sex were included in multivariable analyses except when shown not to be important. Homogeneity of variance was tested using O'Brien's method. ${ }^{20}$ A study of this size is able to detect a $7 \cdot 8$ point real difference in IQ between the genotypes with a power of $80 \%$, assuming an IQ standard deviation of 15 points and a significance level of $5 \%$.

\section{Results}

\section{INTELLIGENCE}

Mean IQ by genotype and test type is shown in table 1 . The mean IQ of SS patients was $5 \cdot 6$ points (95 CI 1.0 to $10 \cdot 2$ ) lower than $\mathrm{AA}$ controls $(p=0 \cdot 016)$, and verbal and performance components of IQ and the derived attention factor were all lower in SS patients (table 2). The variance in IQ was similar in all four genotype/test type groups $(p=0.32)$, and IQ did not correlate with age (partial correlation coefficient $=0.07, p=0.45$ ) or differ with gender (mean difference in $\mathrm{IQ}=3.5$ points $(-1.0$ to $7 \cdot 9)$ higher in males, $p=0.13)$. When stratified by age, genotype IQ differences were similar for both tests, the mean IQ in SS disease being lower for each test at all ages except for the 19 subjects aged 15 years old taking the WISC test.

\section{SOCIAL FACTORS}

There was no genotype difference in parental occupational status, the distribution of skilled, semiskilled, and unskilled being 5\%,47\%, and $48 \%$ for SS patients and $7 \%, 49 \%$, and $44 \%$ for AA controls ( $\chi^{2}$ test for association, $\mathrm{p}=0.85$ ). The number of persons per room, available in $58 \mathrm{SS}$ patients (median 2.3 , range $0 \cdot 4-8 \cdot 0$ ), did not differ from that in $50 \mathrm{AA}$ controls $(2 \cdot 3,0.7-9.0)$ ( $t$ test on $\ln$ transformed data, $p=0.31$ ). There was no genotype difference in the source of water supply, type of toilet, or electricity supply.

There was no genotype difference in absenteeism for the 17 matched pairs who were still in school, absences in SS patients (median 24 days, range $2-175$ ) being similar to AA controls $(14,0-98) \quad(p=0.27$ using the Wilcoxon matched pairs test). School drop out rate did not differ between genotypes, $13 \mathrm{SS}$ patients (six male) and $13 \mathrm{AA}$ controls (seven male) having dropped out of school by the year of the study.

Activity level scores in SS patients (median 45, range 23-55) did not differ from AA controls (48, 23-55) (Mann-Whitney U test, $\mathrm{p}=0 \cdot 13$ )

Adjusting for parental occupation, school attendance, activity level, or domestic environment made little difference to the mean genotype difference in IQ.

\section{CLINICAL SEVERITY}

Among SS patients, the median number (range) of clinical severity related events was 2 (0-18) hospital admissions, 24 (1-81) sick visits, and 2 (0-28) painful crises. After adjustment for test type, there were no significant correlations between IQ and clinical severity (partial correlations for hospital admissions $=-0.16, \mathrm{p}=0.22$; sick visits $=0.06, \mathrm{p}=0.63$; painful crises $=-0.04, \mathrm{p}=0 \cdot 74$ ).

\section{HAEMATOLOGY}

As expected, there were highly significant genotype differences in steady state total haemoglobin, fetal haemoglobin, and MCHC but not in indices of iron status at ages 2 or 8 years (table 3 ). Within SS subjects, the haemoglobin and fetal haemoglobin concentrations, and MCHC were not related to IQ. $\alpha$ Thalassaemia status (mean IQ in 14 subjects heterozygous for $\alpha^{+}$thalassaemia was 1.2 $(-6.0$ to 8.5$)$ points lower than in 44 subjects with a normal $\alpha$ globin gene complement) was also not related to IQ. Adjustment for serum iron concentration and transferrin saturation at ages 2 and 8 years did not change the mean genotype IQ difference.

\section{GROWTH AND DEVELOPMENT}

Mean weights at birth and at 2 years were similar in AA and SS subjects, although weight

Table 3 Relationships between haematology, genotype, and IQ

\begin{tabular}{|c|c|c|c|c|c|}
\hline & \multicolumn{2}{|c|}{ Mean $(S D)$ [median] $^{\star}$} & \multirow{2}{*}{$\begin{array}{l}\text { Genotype } \\
\text { difference } \mathrm{t} \text { test } \\
(p \text { value })\end{array}$} & \multirow{2}{*}{$\begin{array}{l}\text { Correlation } \\
\text { with } I Q \text { in } S S \\
\text { (r) }\end{array}$} & \multirow{2}{*}{$\stackrel{p}{\text { Value }}$} \\
\hline & $A A$ & sS & & & \\
\hline $\begin{array}{l}\text { Haemoglobin } \\
\text { ln (fetal haemoglobin }+1 \text { ) } \\
\text { MCHC }\end{array}$ & $\begin{array}{l}12.1(0.9) \\
0.33(0.23)[0.30] \\
33.0(1 \cdot 1)\end{array}$ & $\begin{array}{l}7 \cdot 6(0 \cdot 9) \\
1 \cdot 70(0 \cdot 69)[4 \cdot 75] \\
34 \cdot 2(0 \cdot 9)\end{array}$ & $\begin{array}{l}<0.001 \\
<0.001 \dagger \\
<0.001\end{array}$ & $\begin{array}{l}-0.17 \\
-0.09 \\
-0.00\end{array}$ & $\begin{array}{l}0 \cdot 20 \\
0 \cdot 49 \\
0 \cdot 98\end{array}$ \\
\hline \multicolumn{6}{|l|}{ Age 2 years } \\
\hline $\begin{array}{l}\text { ln (serum iron) } \\
\text { ln (transferrin saturation) }\end{array}$ & $\begin{array}{l}2 \cdot 3(0 \cdot 6)[11 \cdot 1] \\
2 \cdot 7(0 \cdot 7)[16 \cdot 5]\end{array}$ & $\begin{array}{l}2 \cdot 4(0 \cdot 9)[11 \cdot 3] \\
2 \cdot 8(0 \cdot 7)[18 \cdot 0]\end{array}$ & $\begin{array}{l}0 \cdot 82 \\
0 \cdot 47\end{array}$ & $\begin{array}{l}0 \cdot 18 \\
0 \cdot 19\end{array}$ & $\begin{array}{l}0 \cdot 24 \\
0 \cdot 20\end{array}$ \\
\hline \multicolumn{6}{|l|}{ Age 8 years } \\
\hline $\begin{array}{l}\ln \text { (serum iron) } \\
\ln \text { (transferrin saturation) }\end{array}$ & $\begin{array}{l}2 \cdot 4(0 \cdot 4)[12 \cdot 1] \\
2.9(0 \cdot 5)[18 \cdot 5]\end{array}$ & $\begin{array}{l}2 \cdot 4(0 \cdot 6)[11 \cdot 5] \\
2 \cdot 9(0.6)[23 \cdot 0]\end{array}$ & $\begin{array}{l}0.71 \dagger \\
0.70\end{array}$ & $\begin{array}{l}0.02 \\
0.01\end{array}$ & $\begin{array}{l}0.91 \\
0.93\end{array}$ \\
\hline
\end{tabular}

${ }^{\star}$ Median pretransformation. †Separate variance estimates used for $t$ test. 
Table 4 Relationships between IQ, growth, and genotype

\begin{tabular}{|c|c|c|c|c|}
\hline \multirow[b]{2}{*}{ Covariates } & \multicolumn{2}{|c|}{ Genotype: mean (SD) [No] $\{\text { median }\}^{\star}$} & \multirow{2}{*}{$\begin{array}{l}\text { Genotype } \\
\text { difference } \\
\text { (t test) } \\
\text { ( } p \text { value) }\end{array}$} & \multirow{2}{*}{$\begin{array}{l}\text { Mean genotype } \\
\text { difference in IQ } \\
\text { adjusted for covariate } \\
(95 \% \mathrm{CI})\end{array}$} \\
\hline & $A A$ & $S S$ & & \\
\hline $\begin{array}{l}\text { Birth weight (g) } \\
\text { Head circumference }(\mathrm{cm}) \\
\text { ln (weight } \mathrm{kg} \text { ) }\end{array}$ & $\begin{array}{c}3200(500)[60] \\
34.9(1 \cdot 2)[56]\end{array}$ & $\begin{array}{l}3200(500)[60] \\
34 \cdot 7(1 \cdot 5)[54]\end{array}$ & $\begin{array}{l}0.97 \\
0.33\end{array}$ & $\begin{array}{l}5 \cdot 6(1.0 \text { to } 10 \cdot 2) \\
6 \cdot 1(1.3 \text { to } 10.9)\end{array}$ \\
\hline $\begin{array}{l}2 \text { Years } \\
8 \text { Years }\end{array}$ & $\begin{array}{l}2 \cdot 4(0 \cdot 1)[43]\{11 \cdot 1\} \\
3 \cdot 1(0 \cdot 2)[44]\{22 \cdot 9\}\end{array}$ & 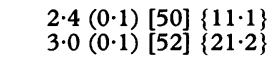 & $\begin{array}{l}0 \cdot 12 \\
0.001\end{array}$ & $\begin{array}{l}5 \cdot 6(0.2 \text { to } 11 \cdot 1) \\
2 \cdot 7(-3.0 \text { to } 8 \cdot 3) \dagger\end{array}$ \\
\hline $\begin{array}{l}\text { Age (years) } \\
\text { At take off } \\
\text { At peak height velocity } \\
\text { ln (sum of skinfolds in cm) } \\
\text { Height z scores (age in years) } \ddagger\end{array}$ & $\begin{array}{l}9 \cdot 6(1.5)[59] \\
12 \cdot 8(1.5)[59] \\
2 \cdot 9(0 \cdot 2)[38]\{18.0\}\end{array}$ & $\begin{array}{l}10 \cdot 8(1 \cdot 2)[60] \\
14 \cdot 2(1 \cdot 5)[60] \\
2 \cdot 8(0 \cdot 2)[44]\{16 \cdot 5\}\end{array}$ & $\begin{array}{c}<0.001 \\
<0.001 \\
0.04\end{array}$ & $\begin{array}{l}5 \cdot 6(1.0 \text { to } 10 \cdot 3) \\
5 \cdot 6(0.9 \text { to } 10 \cdot 3) \\
4.5(-1.5 \text { to } 10 \cdot 6)\end{array}$ \\
\hline $\begin{array}{r}1 \\
2 \\
3 \\
4 \\
5 \\
6 \\
7 \\
8 \\
9 \\
10\end{array}$ & $\begin{array}{l}0.24(1.13) \\
0.35(1.19) \\
0.42(1.31) \\
0.53(1.19) \\
0.52(1.08) \\
0.51(1.08) \\
0.51(1.05) \\
0.61(1.10) \\
0.64(1.05) \\
0.81(1.05)\end{array}$ & $\begin{array}{r}-0.15(1.00) \\
-0.13(1.00) \\
-0.10(0.98) \\
0.03(1.01) \\
-0.09(1.02) \\
-0.21(1.12) \\
-0.18(1.10) \\
-0.22(1.16) \\
-0.19(1.14) \\
-0.19(1.17)\end{array}$ & $\begin{array}{l}0.06 \\
0.02 \\
0.02 \\
0.02 \\
0.002 \\
0.001 \\
0.001 \\
<0.001 \\
<0.001 \\
<0.001\end{array}$ & $\begin{array}{l}5.5(0.6 \text { to } 10.3) \\
4.9(0.1 \text { to } 9.7) \\
4.8(0.0 \text { to } 9.5) \\
4.2(-0.6 \text { to } 8.9) \\
3.4(-1.4 \text { to } 8.0) \\
3.2(-1.5 \text { to } 7.9) \\
3.5(-1.2 \text { to } 8.2) \\
3.1(-1.7 \text { to } 7.9) \\
2.7(-2.0 \text { to } 7.5) \\
2.6(-2.3 \text { to } 7.5)\end{array}$ \\
\hline
\end{tabular}

^Medians before data were transformed. †Relationship between weight at 8 years and IQ not significant after adjusting for height at 8 years. $\neq z$ Scores calculated from standards for SS subjects.

of SS children was significantly lower at age 8 years. Height was reduced in SS children from 2 years, the difference increasing with age (table 4). IQ, at age 15-18 years, correlated with the patients' height at all ages from 1 to 10 years (partial correlations increasing from $0 \cdot 14$ $(p=0.15)$ at age 1 to $0.27(p=0.004)$ at age 10). Adjusting for height for ages 1 through 10 years reduced the genotype difference in IQ to levels that were not statistically significant. The pubertal growth spurt was delayed in SS subjects but adjustment for timing of the pubertal growth spurt made little difference to the genotype difference in IQ.

\section{Discussion}

Previous studies of intelligence in SS disease have been limited by small numbers, imprecise genotype diagnosis, pooling of data from different genotypes, ascertainment biases likely to select more symptomatic children, and suboptimal controls.

Chodorkoff and Whitten found no difference in IQ between patients and sibling controls using the Stanford-Binet or WISC tests for children, ${ }^{21}$ but use of different and not interchangeable tests ${ }^{22}$ may have diminished the sensitivity of this study. Of three recent studies $^{1-3}$ with the WISC-R test in children aged 8-16 years, two reported IQ deficits in SS disease of 16.6 points $^{2}$ and $5 \cdot 3$ points. ${ }^{3}$ The present study with subjects aged 15-18 years required both WISC-R and WAIS-R tests and subsequent corrections for test type, but an IQ deficit of 5.6 points occurred in a larger and more representative group of SS patients and AA controls.

None of the studied social factors appeared to account for this difference. Greater school absenteeism has been reported in SS disease ${ }^{323}$ but did not occur in this study possibly due to the lack of school attendance data at earlier ages or the small sample size. Neither were there any genotype differences in the number or degree of reported social, physical and intellectual activities, parental occupation, density of persons per room, or other social factors. SS subjects were therefore similar to controls in these social and economic indices and adjusting for these variables did not affect the genotype difference in IQ. Neither was there any evidence that IQ within SS disease was related to clinical severity as noted in other studies, ${ }^{124}$ or to haematological indices including iron status.

The relation of growth and IQ produced the most interesting results. No genotype difference occurred in weight at birth, 2 years, or 8 years (after adjusting for height). On the other hand, height was significantly lower in SS disease at all ages from 2 through 10 years and adjusting the genotype difference in IQ for height progressively reduced this difference with increasing age. These observations suggest that a factor common to both growth and mental development may be responsible for these findings.

Early nutrition, especially chronic undernutrition is one such factor in normal children. ${ }^{25-27}$ The type of cognitive deficit found in the SS children with a mild, generalised lowering of IQ with associated attentional deficits, resembles that seen in chronically undernourished children. ${ }^{28}$ The generalised deficit in height, weight and skinfolds, the delayed growth spurt and lower growth velocity, and the delay in sexual maturation seen in SS disease closely resemble the growth and development in chronically malnourished children. ${ }^{29}$ The greater metabolic rate in SS children ${ }^{30-32}$ may also contribute as this predicts greater energy requirements, ${ }^{33}$ and the role of suboptimal nutrition in SS disease is supported by the growth spurt reported with parenteral supplementation. ${ }^{34}$

The lack of a genotype difference in iron status appears inconsistent with a role of early suboptimal nutrition. Serum iron and transferrin saturation are relatively insensitive indices of iron status as they are influenced by erythropoietic activity in the short term and earlier observations in the cohort study revealed higher serum iron in SS disease at ages 1-4 years. ${ }^{35}$ Serum ferritin might have given a 
better indicator of iron status but values in early childhood were not available in the cohort study.

The lack of access to magnetic resonance imaging has not allowed correlation of the IQ findings to 'subclinical' abnormalities of brain structure, and we cannot exclude such changes as a cause of the lowered IQ. However, if these changes were vaso-occlusive in origin, they might be expected to be more frequent in patients with low fetal haemoglobin concentrations and the lack of a relationship of fetal haemoglobin and IQ is against this.

A modest but statistically significant reduction in IQ has occurred in SS disease in the present study and is not attributable to commonly assumed factors such as school absenteeism or disease severity. We are aware of the disquieting nature of these observations but the relationship of lowered IQ with reduced growth in height suggests a potentially correctable mechanism and urges that future studies be focused on early nutrition.

We thank Dr Douglas Higgs of the MRC Molecular Haematology Unit, Oxford for the $\alpha$ globin gene status of these subjects.

1 Fowler MG, Whitt JK, Nash KB, Atkinson S, Wells RJ, McMillan C. Neuropsychiatric and academic functioning of children with sickle cell anemia. Developmental and Behavioural Pediatrics 1988; 9: 213-30.

2 Swift AV, Cohen MJ, Hynd GW, et al. Neuropsychologic impairment in children with sickle cell anemia. Pediatrics impairment in child

3 Wasserman AL, Wilimas JA, Fairclough DL, Mulhern RK, Wang W. Subtle neuropsychological deficits in children with sickle cell disease. Am $\mathcal{F}$ Pediatr Hematol Oncol 1991 13: 14-20.

4 Brown RT, Armstrong FD, Eckman JR. Neurocognitive aspects of pediatric sickle cell disease. Fournal of Learning Disabilities 1993; 26: 33-45.

5 Herold S, Brozovic M, Gibbs J, et al. Measurement of regional cerebral blood flow, blood volume and oxygen metabolism in patients with sickle cell disease usin position emission tomography. Stroke 1986; 17: 692-8.

6 Pavlakis SG, Bello J, Prohovnik I, et al. Brain infarction in sickle cell anemia: magnetic resonance imaging correlates. Ann Neurol 1988; 23: 125-30.

7 Serjeant BE, Forbes M, Williams LL, Serjeant CR Screening cord bloods for detection of sickle cell disease in Jamaica. Clin Chem 1974; 20: 666-9.

8 Wechsler D. Manual for the Wechsler intelligence scale Wech children - revised. New York: The Psychological
for for children - revised

9 Wechsler D. Manual for the Wechsler adult intelligence scalerevised. New York: The Psychological Corporation, 1981: 48-9.

10 Struiksma AJC, Knight S. Wechsler intelligence scale for children - revised: famaicanized version with regrouping of the subtests in factors as suggested by Bannatyne, providing
$I Q$ scores. Kingston, Jamaica: Mico College (internal publication), 1983

11 Bannatyne A. Diagnosis: a note on recategorization of the WISC scaled scores. Fournal of Learning Disabilities 1974 7: 272-3.
12 Achenbach TM, Edelbrock C. Manual for the child behavior checklist and revised child behavior profile. Burlington Vermont: Department of Psychiatry, University of Vermont, 1983

13 Smith MG. Culture, race and class in the commonwealth Caribbean. Kingston, Jamaica: School of Continuing Studies, University of the West Indies, 1984.

14 Statistical Institute of Jamaica. Famaica survey of living conditions 1990. Kingston, Jamaica: Statistical Institute of Jamaica, 1990.

15 Betke K, Marti HR, Schlicht I. Estimation of small percentages of foetal haemoglobin. Nature 1959; 184: 1877-8

16 Beale RN, Bostrum JO, Taylor RF. Improved rapid methods for the determination of iron content and bindmethods for the determination of iron content and bind

17 Stevens MCG, Hayes RJ, Serjeant GR. Body shape in young children with homozygous sickle cell disease. Pediatrics 1983; 71: 610-4.

18 Cameron $\mathrm{N}$. The measurement of human growth. Kent: Croom Helm, 1984.

19 Preece MA, Baines MJ. A new family of mathematical models describing the human growth curve. Ann Hum Biol 1978; 5: 24

20 O'Brien RG. A simple test for variance effects in experimental designs. Psychol Bull 1981; 89: 570-4.

21 Chodorkoff J, Whitten CF. Intellectual status of children with sickle cell anemia. $\mathcal{F}$ Pediatr 1963; 63: 29-35.

22 Littel WM. The Wechsler intelligence scale for children: review of a decade of research. Psychol Bull 1960; 57: review of

23 Fowler MG, Johnson MP, Atkinson MS. School achievement and absence in children with chronic achievement and absence in children with

24 Hurtig AL, Koepke D, Park KB. Relation between severity of chronic illness and adjustment in children and adolescents with sickle cell disease. F Pediatr Psychol 1989; 14: $117-32$.

25 Walker SP. Growth and development of West Indian children. West Indian Med $\mathcal{f}$ 1989; 38: 197-204.

26 Cravioto J, DeLicardie ER, Birch HG. Nutrition growth and neuro-integrative development: an experimental and ecologic study. Pediatrics 1966; 38: 319-59.

27 Hoorweg J, Paget Stanfield J. Intellectual abilities and protein-energy malnutrition: acute malnutrition vs chronic undernutrition. Behavioral effects of energy and chronic undernutrition. Behavioral effects of energy and protein deficits. In: Brozek J, ed. Proceedings of the international nutrition conference. Washingto

28 Hoorweg J, Stanfield P. The influence of malnutrition on psychologic and neurologic development: Preliminary communication. Nutrition, the nervous system and behaviour. Washington DC: Pan American Health Organization, Scientific Publication Number 251; 1972 55-63.

29 Spurr GB, Reina JC. Marginal malnutrition in school-aged Colombian boys: body size and energy costs of walking and light load carrying. Human Nutrition: Clinical Nutrition 1986; 40C: 409-19.

30 Singhal A, Davies P, Thomas PW, Serjeant GR. Resting metabolic rate in homozygous sickle cell disease. Am $\mathcal{F}$ Nutr 1993; 57: 32-4.

31 Odonkor PO, Addae SK, Apatu RS, Yamamoto S. Basal metabolic rate and serum thyroid hormone levels in adolescent sickle cell patients. International Research Communications in Science, Medical Science 1982; 10: 891 .

32 Badaloo A, Jackson AA, Jahoor F. Whole body protein turnover and resting metabolic rate in homozygous sickle turnover and resting metabolic rate in

33 Garrow JS. Resting metabolic rate as a determinant of energy expenditure in man. In: Garrow JS, Halliday $D$, eds. Substrate and energy metabolism in man. London: J Libbey, 1985: 102-6.

34 Heyman MB, Vichinsky E, Katz R, et al. Growth retardation in sickle-cell disease treated by nutritional support. Lancet 1985; ii: 903-6.

35 Serjeant GR, Grandison Y, Lowrie Y, et al. The development of haematological changes in homozygous sickle cell disease: a cohort study from birth to 6 years. Br f Haematol 1981; 48: 533-43. 